\title{
Congratulatory address of the former Director of the Biologische Anstalt Helgoland
}

\author{
Professor Dr. O. Kinne \\ Ecology Institute; Nordbünte 23, D-21385 Oldendorf/Luhe, Germany
}

Ladies and Gentlemen, Colleagues and Friends,

Today the Biologische Anstalt Helgoland celebrates the 100th anniversary of its foundation in 1892. I offer the heartfelt congratulations of the International Ecology Institute in Oldendorf, Germany, representing 51 leading research ecologists from 21 countries and 16 members of the local technical staff.

In the 100 years of its existence the Biologische Anstalt Helgoland has accomplished a great deal: an impressive quantity and diversity of internationally highly recognized publications on in situ research in the North Sea and in other marine environments; on experimental studies on numerous marine and brackish-water animals, plants and microorganisms; $s_{i}$ on comparative and descriptive research in the fields of organismic distribution, life histories and taxonomy. The Biologische Anstalt Helgoland also has a long, distinguished tradition of teaching marine courses. In fact, for a century, the BAH has been one of the world's focal points in marine ecology and marine biology.

On Helgoland and Sylt, thousands of biologists have made their first contact with the sea and its multitude of organisms. For many of them - including myself - this experience turned out to be a decisive factor for their future professional life and for inspiring a lifetime of research on the marine biota.

For almost a quarter of the Anstalt's 100 years of existence, I served as its director. I remember that time and my responsibilities then as a privilege, a challenge, a burden depending on the perspective and historical development. Please allow me to add a few personal words.

My first encounter with the Biologische Anstalt Helgoland was in 1948. All buildings on Helgoland had been destroyed at the end of the Second World War. The remaining staff and equipment were being accommodated in several private houses at List on the island of Sylt. At the time a student at the University of Tübingen in southern Germany, I participated in a two-week marine biology course at List. Viewing marine plankters through a microscope immediately captured all my attention; more than that, it caused vibrations that I can feel to this day. Exciting excursions into the Wadden Sea and boat trips, too, left indelible memories.

While the marine biology course made a protound impression on me, $l_{1}$ in turn, impressed the Director, Professor Hagmeier - not with my knowledge, mind you, nor with my performance, but by harassing his chịckens. I enjoyed simulating the voices of 
roosters and hens and, thus, repeatedly caused an uproar among them. When Hagmeier wanted to feed his precious birds at one point in his garden, I made them run in the opposite direction, toward me. At the end of the course, Hagmeier said goodbye to us. Suddenly he turned to me and said, 'And you are the one who caused my chickens to have a nervous breakdown!' Certainly, I had impressed him.

My second encounter with the Anstalt was in 1960. Then Associate Professor at the University of Toronto, Canada, I had been invited to attend a small conference on benthic marine animals on Helgoland.

The third time I came to the Biologische Anstalt Helgoland was in 1962, as its newly appointed director.

In the early 'sixties, the Biologische Anstalt Helgoland was in bad shape. As the fifth institute of the 'Bundesforschungsanstalt für Fischerei', its scientific performance and its general impact had degenerated into mediocrity. A separation from applied fisheries research and a tremendous amount of work was required, as well as new ideas, administrative changes and a lot of enthusiasm. Only after years could the seemingly impossible be accomplished: the Biologische Anstalt Helgoland again joined the small group of world-wide leading marine biological institutions.

At this centennial celebration, I would like to thank all those who helped to make this possible: my co-workers and associates of that time, and the Federal Government in Bonn, at the outset the Ministry of Agriculture and Forestry and, later on, the Ministry of Research and Technology.

It is a great pleasure for me to see so many colleagues and friends of long-standing here, many of whom attended one or several of the International Helgoland Symposia which I initiated and organized in the 'sixties, 'seventies, and 'eighties. These symposia were instrumental in catalysing cooperation among marine biologists in Europe and around the world, and in bringing new life and vigour to the Biologische Anstalt Helgoland. I hope that this centennial celebration will also mark the rebirth of this important and successful conference series.

Looking into the future, the Biologische Anstalt Helgoland faces new and significant challenges in a rapidly changing world that is more than ever in need of knowledge about the seas which cover two-thirds of its surface area, and which decisively affect the earth's climate, provide resources, and hold the keys to a better understanding of life on earth that originated in its waters.

May the Biologische Anstalt Helgoland successfully continue to play its role among the world's leading marine biology institutions and may its sponsor, the 'Bundesminister für Forschung und Technologie', find the wisdom, power and courage to provide a safe and sound basis for the Anstalt's work in its second century! 